\title{
Jay Fox: A Journey from Anarchism to Communism
}

\section{Greg Hall}

Soon after dropping out of school at the age of fourteen, Jay Fox began his working life in a Chicago cabbage patch. For fifty cents a day, he planted cabbage plant seedlings in the spring and was part of the harvest later in the year. ${ }^{1}$ The cabbage work was seasonal, so Fox drifted into other employment until he landed at job at the Mallable Iron Works in fall 1885. At the foundry, he worked in the trimming room for seventy-five cents for a ten hour day, six days a week. Sometime during those first weeks of factory employment, he joined a local assembly of the Knights of Labor. Fox continued to work steadily at the foundry until the city-wide strike of May 1, 1886. He then became a picket, which he recalled as "my first active participation in the class struggle." 2 Out of curiosity that day, he left his workers' picket line and went over to the picket line near the McCormick works that was just a couple of blocks away, where laborers were also on strike. Soon after he took up a spot on the line, scabs - with a contingent of police - arrived to break through the picket line. A melee ensued, resulting in the deaths of several striking workers and the injury to many more, including Fox who was grazed in the arm by a policeman's bullet. ${ }^{3}$ At that point, Fox became a radicalized worker. Further solidifying his commitment to bettering the lot of his fellow workers was the subsequent Haymarket tragedy and the anarchist martyrdom that followed. These events seared in his mind a desire to emancipate the working class, a cause that he would actively pursue for the next forty years. 4

As a largely self-educated Chicagoan, Jay Fox was a radical advocate for the most revolutionary means to address the needs of the American working class in the late nineteenth and early twentieth century. Even though he started his working life as a laborer, he primarily worked as a journalist and as a newspaper editor in the cause of labor's emancipation from "wage slavery." For most of Fox's life he considered himself an anarchist, though his anarchism was never a static ideological system but one that was constantly evolving. Nevertheless, his anarchism was of the anarchist communist variety rather than that of anarchist individualism, which were the two primary strains of anarchism in the United States. Unlike many anarchists of his generation, he always tried to integrate anarchism into the labor movement and to use an anarchist critique of society in his writing to assist in the intellectual liberation of American workers. Over the course of three decades of publishing, Fox embraced several organizing strategies, most specifically revolutionary industrial unionism, syndicalism, and later the American communist movement. Moreover, Fox consistently put his ideals into practice. He was a labor delegate at the founding of the Industrial Workers of the World in 1905. Later, he assisted in the creation of an industrial union of 
loggers, mill workers, and shingle weavers in the Pacific Northwest with the International Union of Timber Workers. He served as a vice president of the union and editor and journalist for the international's newspaper, the Timberworker. For a number of years he was a labor organizer with the American Federation of Labor while writing for a series of labor newspapers in Chicago and Seattle. In addition, Fox was a long-time and active member of the anarchist Home Colony, on the banks of Joe's Bay in Washington's Puget Sound.

Jay Fox does not fit easily into the scholarship of labor movement history, for he was not one of the voiceless masses of workers toiling in obscurity nor was he a powerful leader who commanded a large following. Nevertheless, he was a significant historical participant in the arc of American labor radicalism and a clear representative of an only partially understood element of the working class, the "militant minority." According to labor historian David

Montgomery, "Both 'history from the bottom up' and the common fixation on great leaders have obscured the decisive role of those whom the twentieth-century syndicalists have called the 'militant minority'; the men and women who endeavored to weld their workmates and neighbors into a self-aware and purposeful working class." 5 This is precisely the role that Fox played, especially in Chicago and Seattle, as a journalist, public speaker, community organizer, and labor union official. His goal was to build a radical community of activists who would help direct the working class to challenge the forces of capitalism and the autocratic power of employers. These core activists - anarchists, syndicalists, and communists - would provide an alternative vision of a more just and humane society and help guide the working class into creating it.

Jay Fox is a distinctive member of that cohort of working class activists in that he left behind a large body of published literature, unpublished manuscripts, correspondence, along with other documents. These "traces" of his historical past provide a window into the evolution of his thinking and methods as a labor activist as well as into the thinking and methods employed by his cohort, many of whom left little in the historical record. ${ }^{6}$ An historical analysis of Fox's life work answers the call by David Montgomery to investigate this underdeveloped area of labor movement history and falls into line with recent studies by historians such as Rosemary Feurer, David Berman, Randi Storch, and Peter Cole who have examined the decisive role that core groups of radicals played in attempting to formulate "a self-aware and purposeful working class."7

Additionally, a study of Fox's journalistic activism, as he evolved from anarchist to syndicalist to communist, reveals popular rank and file support for radical ideas, particularly in the labor press. Fox exemplifies, unlike few historical agents of his era, the evolution of the ideas and strategies of American labor radicals from the 1880 s to the 1920s. Finally, for Fox and for other radical labor activists 
of his era moving from member of the "militant minority" in the labor movement to member of the communist party was not so great a leap.

Jay Fox was at the Haymarket gathering that ended with a bomb blast and a hail of policemen's bullets. He followed the trial of August Spies and Albert Parsons and the other anarchists and marched in the funeral procession of those who were executed. The anarchist and communist theory that he was exposed to in the speeches he heard at Haymarket and read in the English language labor and radical press of Chicago had a significant impact on his intellectual development, though it would be a number of years before he became a self-conscious anarchist communist. In the meantime, he became a blacksmith by trade, began writing for the labor press, and maintained his membership in the Knights of Labor. In 1893, he secured a job at the Illinois Central Railroad shop in Chicago and due to the influence of his friend Jim Finn, an engineer, he joined the American Railway Union (ARU). He readily embraced an industrial union of railroad workers, having already been exposed to the industrial union concept as a Knight, and had great admiration for Eugene Debs' leadership of the union. Fox was a delegate at the first convention of the ARU and voted to support a relief fund for striking Pullman shop workers and a boycott of Pullman sleeper cars. Despite the initial success of the ARU action, the arrest of Debs for breaking a court injunction, the federal government's direct intervention, and the depletion of union strike funds led to the collapse of the strike and to the young ARU. ${ }^{8}$

Fox left railroad employment and took his metal working skills to a new field of manufacturing: bicycles. He was gainfully employed for a couple of years until the bike shop that he worked at suddenly closed. Not knowing if he would ever receive his final paycheck, he decided to take a bicycle from the shop in lieu of wages. Maybe not coincidently, he decided that it was a good time to leave Chicago and to see some of the country and the world. At this point in his life, he had a clear interest in the anarchist press. Fox left the city in the summer of 1896 and traveled by bicycle to Boston. According to Fox, it was a "Hub" of American anarchism. He supported himself as a traveling mechanic and as a visiting newspaper columnist in some of the small towns he encountered along the way. Arriving in Boston, he looked up Harry Kelly, having been impressed with the anarchist's The Rebel. Fox was not in Boston long, though, before he decided to travel to England. He found work on a ship taking cattle to Liverpool. Soon after arriving, he found a job in a bicycle shop in Birmingham, though he did not remain long before he made his way to London to seek out the anarchist group in the city that was affiliated with the newspaper Freedom. In London he was exposed to the outdoor soap boxing of London's anarchists and soaked up the milieu of the city's anarchist community. After spending a year in England, he returned to Chicago committed to anarchism and to writing for the English 
language anarchist press. ${ }^{9}$

Fox's first published work in a self-identified anarchist newspaper was in the pages of Free Society. The newspaper first came into existence as the Firebrand, which was published in Portland, Oregon, beginning in January 1895, by the editors Abe Isaak, Henry Addis, and Abner J. Pope. Their goal was to bring a discussion of anarchist communist ideas to the English-speaking public across the United States. Postal authorities, however, suppressed the publication for violating obscenity laws after the editors published the Walt Whitman poem "A Woman Waits for Me." Isaak resumed publication of the anarchist communist newspaper in San Francisco as Free Society in 1897. Fox's work was published in Free Society while it was located in San Francisco, but also when the newspaper moved to Chicago (fig. 1), and still later New York City. ${ }^{10}$ While living in Chicago, a twenty-something Fox wrote on a variety of labor, social, and cultural topics, along with updates on the anarchist movement in Chicago.

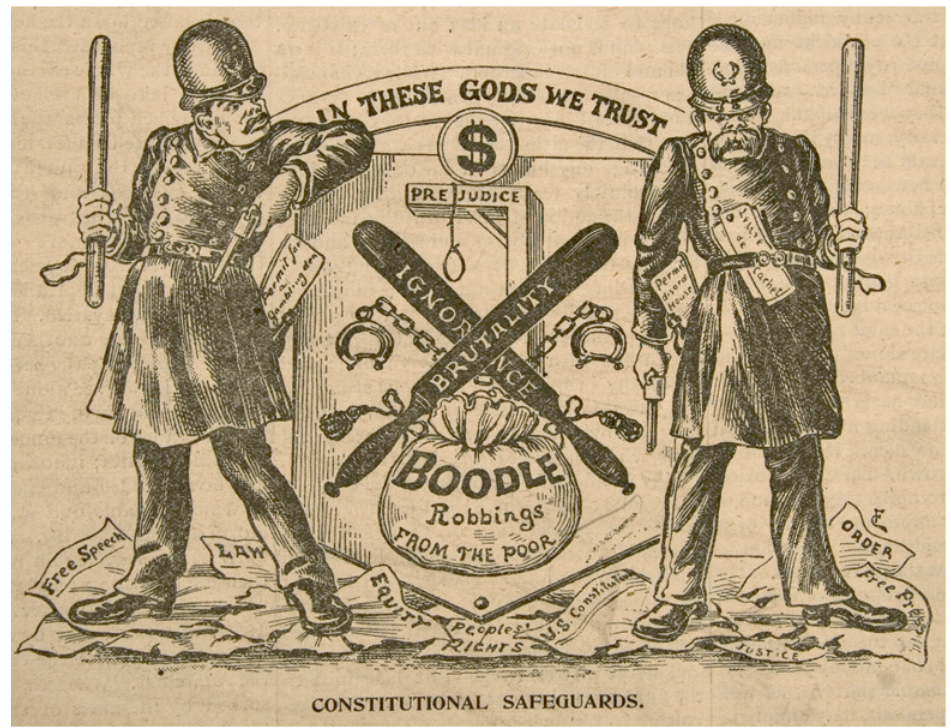

Figure 1. Free Society masthead c. 1900. (Courtesy, Newberry Library, Chicago, Illinois)

He supported himself as a blacksmith and as a machinist, though his writing took up an increasing amount of his personal time. ${ }^{11}$ From 1897 to 1904, his writing in Free Society can be distilled down to a number of basic tenets and convictions that he would bring with him to the anarchist Home Colony, his later journalistic career, and his subsequent work with mill and timber workers in the Pacific Northwest. In the pages of Free Society, Fox advocated the concept of the 
Brotherhood of the Co-operative Commonwealth. In the wake of the massive failure of reform politics in the election of 1896, Eugene Debs, other socialists, and Populists initially supported the plan. Fox, as an anarchist, found this nonstatist path toward socialism laudable. Eventually, Debs backed away from radical colonization of the West in favor of political action to achieve socialism in the United States. Fox, though, remained faithful to the idea that territories or recently created western states could be converted into a peaceful revolutionary wave that would begin in the West and wash over the rest of the country. ${ }^{12}$ This helps to explain in part why an urban-born wageworker and anarchist would move to the remote location of Home Colony ten years later. ${ }^{13}$

One of the major themes in Fox's early writing was the labor movement and the struggles particular to the working class. Like other anarchists and later syndicalists, such as Errico Malatesta, he advocated the general strike as the most effective revolutionary tool that workers had at their disposal. ${ }^{14}$ In fact, some scholars, namely Michael Schmidt and Lucien van der Walt, contend that "syndicalism, in essence, is an anarchist strategy, not a rival to anarchism." 15 Much of Fox's writing and organizing would exemplify that assertion. In a piece entitled "Trade Unionism and Anarchism" Fox laid out his explanation for the role that anarchists played in labor organizing, emphasizing that it is only through the power of labor unions that workers can affect change in the work place. To rely upon politicians, the state, or the legal system would be a mistake for workers because the only power that they have is at the point of production. Labor unions themselves - with workers organized by both trade and industry - would replace individual (or corporate) ownership of the means of production and the structures of the state, which he contended were both enemies of the working class. This essentially syndicalist strategy was at the foundation of his economic and political thinking for the next two decades. ${ }^{16}$

Although the anarchist community in Chicago seriously diminished by the 1890s, Fox, Lucy Parsons, and a number of other anarchists, kept the spirit of anarchism alive in the city. ${ }^{17}$ Fox was a prominent member of the city's anarchist affinity group and maintained connections with other like-mined affinity groups across the country. Small communities of anarchists could be found in several major cities such as New York, Boston, Philadelphia, Cleveland, and San Francisco. A significant means to maintain a sense of community and to bring an anarchist perspective to the public was the Social Science Club of Chicago. Such clubs could be found wherever a community of anarchists resided in the 1890s and 1900s. The club in Chicago, where Fox frequently spoke, was a forum for the discussion of anarchist ideas and a venue for lectures on a variety of topics that ranged from labor to women's rights to imperialism. Further revitalizing the anarchist presence in Chicago was the relocation of Free Society to the city in 
January $1901 .{ }^{18}$ Abe Isaak continued to edit the newspaper, and Fox would spend time at the Free Society office, when not working as a blacksmith. Chicago was on its way to being again viewed as a center of radicalism as it became a major stop for anarchists such as Emma Goldman, Johann Most, and Peter Kropotkin along with other radicals and free thinkers. In August of that year, a young man named Neiman, who claimed to be an anarchist from Cleveland, introduced himself to Isaak and Fox. After a few conversations, however, they both found Neiman suspicious and possibly an agent provocateur. In the next issue of Free Society, the editor posted a warning about him. Neiman turned out to be none other than Leon Czolgosz, the assassin of President William McKinley. ${ }^{19}$

Soon after the shooting, police arrested anarchists they sought in connection with Czolgosz; among them were Emma Goldman, Fox, and Isaak. Fox was in the city jail for thirty days when investigators finally concluded that he and none of the anarchists under arrest in Chicago had anything to do with a conspiracy to kill McKinley. Nevertheless, the public attitude toward anarchists was violent, particularly as expressed in the nation's newspapers. President Theodore Roosevelt went so far as to claim that all "Anarchist speeches and writings are essentially seditious and treasonable." Within the context of this atmosphere, Fox felt compelled to write a pamphlet, explaining the nature of anarchism. ${ }^{20}$ Roosevelt, Czolgos\%, and Anarchy appeared in 1902. Fox used the pamphlet as a way to explain why Czolgosz would resort to such an extreme act of protest. In the pamphlet, Fox noted the oppressive acts of the federal government against workers who struggled against exploitive employers and of the violent suppression of Filipinos in their struggle against American imperialism. Anarchism, according to Fox, had little to do with Czolgosz's act, for the man was "Tortured to the limit of endurance by the sight of a suffering humanity." Fox went on to argue that all forms of government are inherently oppressive, and he cited numerous well-known historical figures who supported that claim by invoking the ideas and writings of Thomas Paine, Thomas Jefferson, William Lloyd Garrison, Henry David Thoreau and of European thinkers such as Leo Tolstoy, Edmund Burke, and Herbert Spencer and of course anarchists such as Peter Kropotkin and Pierre-Joseph Proudhon. His point was not that they all supported an anarchist theory of society but that, from his perspective, they championed liberty and freedom from oppression. It is clear in the pamphlet that at its heart Fox's anarchism was a libertarian social philosophy and that should not be alien to Americans or to be feared. According to Fox, "Under Freedom - Anarchy - an enlightened public opinion will take the place of laws and jails. The basis of society being love and comradeship instead of brute force ..." For Fox, anarchism promised a kind of secular millennialism that would usher in "Peace, Love and Brotherhood" as the "inevitable consequences of 
Anarchy." In order to achieve an anarchist future, the people must emancipate themselves. It is their ideas "that enslave them" not a ruling elite. Killing a tyrant, he contended, will not free the people. Therefore, the spread of ideas through the written word was essential to Fox's life's work. ${ }^{21}$

Due to the encouragement of some East Coast anarchists, Isaak, along with members of his family, moved Free Society to New York where there were varying levels of support among the anarchists of the city. Saul Yanovsky, editor of Freie Arbeiter Stimme - a Yiddish language anarchist newspaper - did not like the competition, at least according to Fox. Emma Goldman, however, was far more supportive. Although there were a number of foreign language anarchist newspapers in circulation, Free Society was one of the few English language anarchist communist newspapers circulating in the country at the time. Fox (fig. 2) went along with the Isaaks and Free Society where he wrote for the newspaper until it ceased publication in 1904. ${ }^{22}$ Accompanying his writing career, he was a featured lecturer on a number of topics relating to labor and to anarchism. Most of these public speaking engagements occurred in New York and Boston. ${ }^{23} \mathrm{He}$ had a reputation within the anarchist circle of New York as an insightful commentator on the current state of the labor movement and strategies that the working class could employ to overthrow the existing economic system. ${ }^{24}$

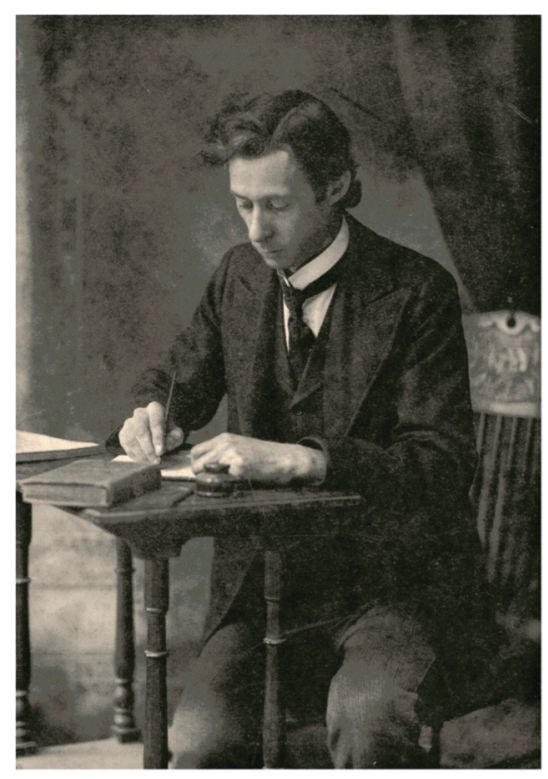

Figure 2. An early photograph of Jay Fox taken in New York City in 1902. (Courtesy, Special Collections Division, University of Washington, Libraries) 
Without Free Society, Fox, who could only write in English, needed another venue for his anarchist writing. He found that new outlet with The Demonstrator, one of a series of Home Colony's anarchist newspapers. Founded in 1896, the colony, which had emerged from the collapse of several other cooperative colony efforts in Washington and which had developed a decidedly anarchist as opposed to a socialist orientation, became a major contributor to the anarchist press on the West Coast. Home Colony was a diverse community of over one hundred members, consisting mostly of families. The anarchism of the community was primarily of a social libertarian variety, though those associated with the newspapers were decidedly anarchist communist. ${ }^{25}$ By 1905 , Fox returned to Chicago and became immersed in the city's labor movement. His first article in The Demonstrator concerned the formation of the Industrial Workers of the World (IWW, members were also known as Wobblies) in which he acted as both correspondent and union delegate. ${ }^{26}$ Later that fall, The Demonstrator officially endorsed the IWW. In December, members of the community sought Fox as a replacement for James F. Morton Jr., the community's newspaper editor. Fox wanted to use this opportunity to expand The Demonstrator into an eight-page anarchist weekly. In Chicago, the English-speaking anarchist circle wanted to establish a paper to spread their ideas and to share some of the burden of education being waged by the foreign-language anarchist press. How this was to be achieved created a rift among Chicago anarchists. Some insisted that a paper needed to be produced in an urban environment so as to be firmly connected to the labor movement. According to these advocates, such as Lucy Parsons, Chicago should be the center of anarchist agitation. The city's radical tradition and reputation as the most unionized city in America seemed to support the argument. Others, though, namely Fox, were more pragmatic and suggested that "A paper published in the backwoods of Washington" could be effective. The cost of living was very low in the community and plenty of volunteer labor would be available to produce the publication. Moreover, he reminded his comrades that it was not that long ago that the best English language anarchist newspaper with a national circulation was published out of Portland, Oregon, the Firebrand. ${ }^{27}$

In August 1907, The Demonstrator became a self-proclaimed anarchistcommunist journal, though the contributors had always leaned in this direction. Furthermore, it shed any official association with Home Colony or the Mutual Home Association, thereby freeing it from interference by any individualist anarchists of the community, even though it was still being published in the Puget Sound village. The Demonstrator group, a number of like-minded Home residents, took control of the paper. ${ }^{28}$ Even though the Brotherhood of the Cooperative Commonwealth movement had faded by this time, Home colonists' commitment to anarchism as well as to the labor movement assisted Fox in making his deci- 
sion to relocate to the colony in the winter of $1908 .{ }^{29}$ Nevertheless, he did not arrive in time to save The Demonstrator, which was under serious financial strain. It ceased publication before he could take over as editor. Initially, Fox did not stay in Home for long, for he had to relocate to Seattle to find adequate employment. Once he had enough funds, he could afford to bring his family with him from Chicago, Esther Abramowitz and two of her children from a former marriage. ${ }^{30}$ It was not until 1910 that Fox was able to begin a new paper, The Agitator (fig. 3). According to Charles Govan, a long time member of the community, support for "the movement" was at low ebb, though the resources of Home colonists were better than they had ever been. ${ }^{31}$ It may have taken a couple of years to achieve the necessary support, but The Agitator finally made its appearance in November 1910.

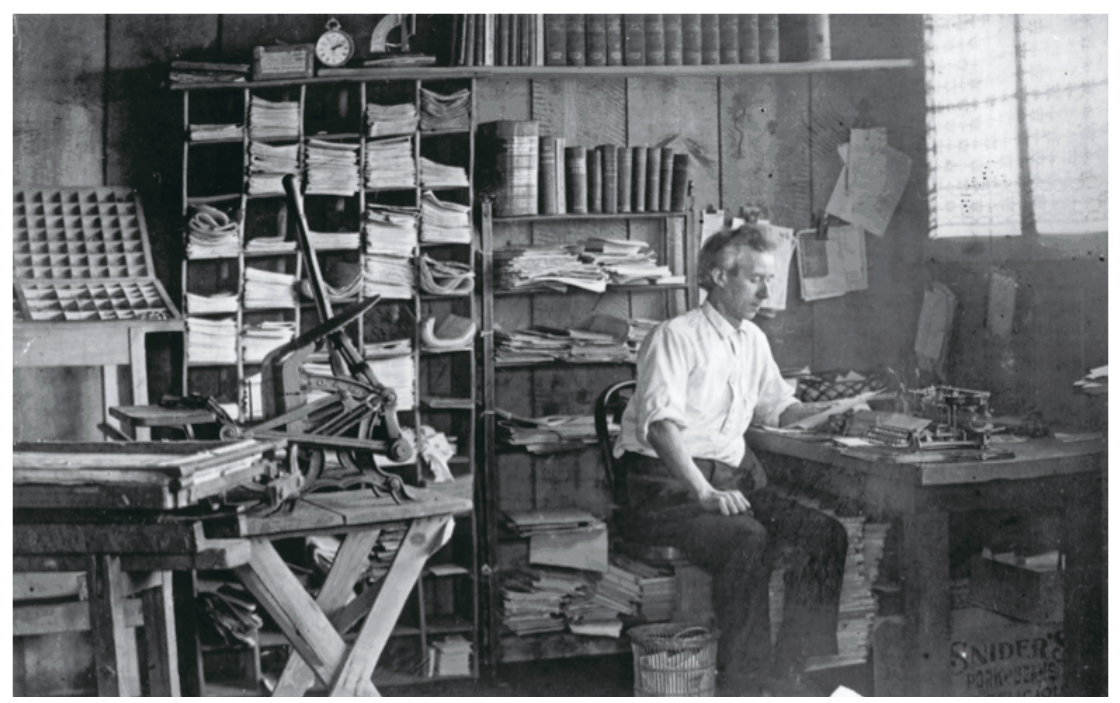

Figure 3. Fox at work as editor of The Agitator c. 1910. (Courtesy, Special Collections Division, University of Washington, Libraries)

With Fox as its editor, the newspaper possessed a major focus on the labor movement and complemented Emma Goldman's Mother Earth. Her magazine was out of New York and included works of fiction, poetry, reviews, as well as political and social commentary. ${ }^{32}$ Fox thought that Home Colony was the perfect place for The Agitator because of the community's simple, but effective, eighteenth century printing press, the area's low cost of living, and donated labor, especially that of George Jones, a resident printer by trade who could instruct Fox in setting type and other aspects of newspaper publishing. ${ }^{33}$ The Agitator began its life as an advocate for "Industrial Unionism for the parent, the 
Modern School for the child, [and] Freedom for both." 34 Fox thought of the new publication as an educational organ for the working class, bringing to them the ideas of Karl Marx, Kropotkin, Proudhon, and Charles Darwin among others. He encouraged Agitator groups to form around the country in support of the publication through writings and donations. ${ }^{35}$ Some of the best support for The Agitator could be found on the West Coast, especially IWW locals in Seattle and Spokane. ${ }^{36}$ A regular feature of The Agitator was Fox's "The Passing Show" columns in which he dealt with a series of issues, mostly national but a few local and regional. ${ }^{37}$

To the south in California, a particular focus of his attention was directed at the open shop drive by Harrison Gray Otis, the editor and owner of the Los Angeles Times. When the Times building was blown up in October 1910, apparently in retaliation for Otis' antiunion rants in his newspaper, a number of labor organizers fell under suspicion by local police. Law enforcement officials arrested union organizers James and Joseph McNamara for the bombing, though other suspects continued to be pursued. Rumors spread that two suspected accomplices, Matthew A. Schmidt and David Caplan, had made their way to Home to hide out. The William J. Burns Detective Agency, which the city of Los Angeles hired, pursued the suspects. Burns himself was one of the agents who went to the colony. Fox was among those under surveillance. Though the detectives found nothing, some evidence exists that Fox knew of Caplan's whereabouts. There is some indication that Caplan had stayed briefly at Home and also hid out on Bainbridge Island. ${ }^{38}$

Fox's involvement in assisting Caplan elude authorities is inconclusive, but he was very forthcoming in regard to his position on violence as a strategy to advance the interests of labor and the working class generally. He, like many labor advocates, believed in the innocence of the McNamara brothers and urged labor organizations to assist in their defense and applauded those organizations and individuals that did. For Fox, this was a classic battle between labor and capital with the state framing a case against labor organizers. ${ }^{39}$ When the McNamara brothers confessed to the crime, Fox placed their actions within the context of a "great social war." He did this in a similar manner as he had with Czolgosz. He did not necessarily support the actions of the men because of the deaths resulting from the bomb blast, but he understood their actions as part of a larger struggle to defeat industrial capitalism, a system of exploitation that brought about the deaths of thousands of working people every year in mining accidents, railroad mishaps, and workplace fires, much of which could be prevented if the drive for profit over human life did not dominate the economic system. ${ }^{40}$

Of course, the most effective strategy that workers could employ to advance their interests was to organize into labor unions. In his newspaper, Fox 
championed the IWW as a true form of revolutionary industrial unionism that could create the "future society within the shell of the old," though he did not give up on non-IWW elements of the labor movement. He had plenty of criticism for Samuel Gompers and the conservative leaning American Federation of Labor (AFL). Nevertheless, he called for radicalizing more conservative labor unions, making them vehicles for revolutionary change through the efforts of a "militant minority" 41 of anarchists, who avoided associations with political parties. In essence, he was keeping the "Chicago idea" alive that was the brain-child of Parsons and Spies back in the 1880s. Parsons and Spies were improving upon a strategy, which had its origins in Europe in the 1860s and 1870s among anarchists influenced by Proudhon and Mikhail Bakunin. Just as anarchists before him developed innovations in labor strategies, Fox promoted the syndicalist "general strike" as the ultimate revolutionary tactic. As stated earlier, the first examples of his syndicalist convictions could be found in the pages of Free Society, later further developed in his pamphlet Trade Unionism and Anarchism. ${ }^{42}$

Syndicalism became a more pronounced presence in The Agitator in early 1912 around the time that Fox became friends with William Z. Foster, a frequent visitor to Home. Foster, at the time a member of the IWW, had been trying to spread his ideas regarding syndicalism in the labor press. He was greatly influenced by European syndicalists, especially the French. He had several articles published in Solidarity, one of the IWW's newspapers. He was particularly interested in promoting what he had learned in France of the "militant minority" who would "bore from within" existing unions and radicalize them. He also pulled no punches when providing a critical analysis of labor organizing and its revolutionary potential. To the displeasure of some Wobblies, Foster called into question the IWW's basic strategy of creating a revolutionary industrial union structure. He argued that the IWW should focus on radicalizing existing unions rather than creating an alternative labor federation. At that point, the editor of Solidarity abruptly shut down Foster's series of articles. Fox, though a supporter of the IWW, decided to open the pages of The Agitator to Foster's ideas. ${ }^{43}$ Foster's series in The Agitator was under the heading "Revolutionary Tactics" in which he laid out his critique of organized labor and offered his view of a syndicalist alternative. He also wrote several articles in The Agitator that outline the history of syndicalism in France. ${ }^{44}$

Foster had a very strong impact on Fox, who began to see the need for something that would replace the failed efforts of the IWW to create an alternative revolutionary labor federation. In its place a syndicalist effort was necessary to radicalize existing unions. Fox, like Foster, argued for radical American labor organizers, the "militant minority," to emulate the French syndicalists who bored from within existing unions to strengthen, rejuvenate, and radicalize them and to only create unions when they did not exist in specific trades or industries. Later 
in 1912, Fox distinguished syndicalism from the IWW, though his critique seems to have been one based on tactics rather than the ultimate goal, for both were revolutionary paths that led to a society without government and organized through democratically managed industrial unions. He did not think that the two systems were synonymous. Furthermore, he argued that the IWW was actually hurting the labor movement because it was pulling radicals out of existing unions into the IWW. Subsequently, when the IWW failed to grow, radicals found themselves isolated from the working class, leaving conservative unions to dominate the labor movement. Nevertheless, Fox noted that he would continue to support Wobblies when their actions were in the best interests of the working class. He would not disown them for they had a valuable role to play in workers' emancipation, especially when organizing the unorganized. ${ }^{45}$

In late 1912, Fox made a dramatic move. Under the influence of Foster, he decided to move himself and his newspaper to Chicago. Foster convinced him that the newly-formed Syndicalist League of North America (SLNA), centered in the Second City, needed a newspaper and The Agitator with Fox as its editor was a perfect fit. In a letter to his longtime anarchist friend Jo Labadie, Fox wrote,

Say, Jo, what do you think, I'm going back to Chicago. This berg is become too small for the A. [The Agitator] It's outgrown the state. We want to take the center of the Industrial stage. The Syndicalists want me to go there and make the paper the central organ of the movement. And this movement is going to grow, Jo. It's better than our pure and simple anarchy at this stage. I'll make 'em anarchists and they won't know it. It's a sugar coat as it were. ${ }^{46}$

Fox's letter reveals his desire to be at the center of the revolutionary movement, labor activism, and to keep anarchism alive among the working class and within syndicalism. On this last point, he obviously did not think that all syndicalists were indeed anarchists and thought that it was an important role that he could play to keep this "militant minority" sufficiently anarchist, in effect "boring within" those who were "boring within." The Agitator reappeared as The Syndicalist published out of Chicago in January 1913. Before leaving the Northwest, he made an appearance at the Labor Temple in Vancouver, B. C. to spread the syndicalist message. He also made clear in The Syndicalist the newspaper's role in promoting syndicalist leagues and disseminating syndicalist ideas, the most important of which was for radicals to radicalize existing unions and not join the IWW to create a dual federation. On his way to the Midwest, he made stops in Butte, Montana, and Minneapolis, Minnesota, to spread syndicalism as a body of ideas that workers could implement into their existing unions. ${ }^{47}$ Once Fox arrived in Chicago and began working as editor of the newspaper and as advocate of the 
SLNA, he felt rejuvenated and quite hopeful for the workers' revolution.

According to one scholar Fox and Foster operated the SLNA and the newspaper out of the Lucy Parsons' home in the Near West Side of Chicago. Fox's primary duties centered, of course, on the newspaper, though he did engage in public lectures on a variety of subjects. ${ }^{48}$

The SLNA turned out to be a short-lived organization, and it never advanced beyond its embryonic stage. Fox believed "that sufficient preparatory work had not been done before starting the new line of propaganda that required more than the usual explanation." 49 Within several years syndicalist league affinity groups in cities such as St. Louis, Kansas City, and San Diego dispersed and the newspapers associated with them suspended publication indefinitely. The Syndicalist, despite the efforts by Fox and Parsons (who also wrote for the paper) to increase subscriptions and circulation, folded at the end of 1912. Foster tried to keep the faith alive with a "syndicalist conference" held in St. Louis in 1915. One outcome was the creation of the International Trade Union Educational League (ITUEL) of which Jay Fox was an executive board member. ${ }^{50}$ However, before this effort to revitalize syndicalism, Fox tried to put his commitment to the cause into practice back in the Pacific Northwest, figuring that syndicalism was bound to succeed in time. ${ }^{51}$

Fox returned to Seattle in 1913 where the AFL was holding its annual convention. At the meeting, he met Jay G. Brown, president of the Shingle Weaver's union, who had a proposition for him. Brown may have been aware of Fox's interest in lumber and timber workers of the Pacific Northwest. In one issue of The Syndicalist, Fox had argued that the IWW had failed to organize the thousands of mill workers and woodsmen in the region after seven years of trying and that the AFL had not done much better. He also championed a Ballard, Washington, shingle weavers strike in April in the pages of The Syndicalist.

Brown's proposition was for Fox to attend his union's convention. He was in the process of transitioning his union from trade to industrial, so that "the entire industry, logging, mill work and shingle weaving" was brought into one large industrial union rather than divided among crafts or trades. The Shingle Weavers were affiliated with the AFL as was the industrial United Mine Workers (UMW) union. John Mitchell, the president of the miners' union, supported Brown and his effort. To Brown's surprise he easily received an industrial charter from the AFL. In addition, the new International Union of Shingle Weavers, Sawmill Workers, and Woodsmen had financial support for Brown to hire two organizers. He chose Foster and Andy Raymor, a shingle weaver, as his industrial organizers. He selected Fox to edit a new version of the Timberworker, the union's newspaper. ${ }^{52}$ 
In some respects, Fox's work with the union and acting as editor of the newspaper were the culmination of a life's goal to bring anarchism to the working class and assist in its emancipation. He was no longer the outside agitator or ecumenical labor journalist or anarchist critic. Now he was working within the AFL, building an industrial union with a syndicalist vision. ${ }^{53} \mathrm{He}$ was still an anarchist but now an active member of the "militant minority." The means by which he could be most influential, of course, was through his writing. Fox had high hopes for the newspaper. He believed that too many labor papers were "devoted to drab, generally unimportant union matter of no educational value, and little read as a result." He wanted the Timberworker to be "both interesting and instructive." His primary editorial venue in the paper was his "Letters to Jack Lumber" column. Here he employed an interactive conversational style of editorializing that he had developed over the years in several different forums, the most successful of which was "The Passing Show" in The Agitator and The Syndicalist. ${ }^{54}$

Fox devoted most of the space in his columns to pragmatic means by which workers could employ to better their conditions in the here and now. Even though he continued to believe that a world without the state and capitalism was possible, he focused on promoting labor organizing, especially industrial labor unions. Drawing on a cause that was dear to him since his days as a wageworker in Chicago, he stressed the eight-hour day as a benefit for workers because it would facilitate more employment and enable the worker to do more with his life than to be constantly at labor. ${ }^{55}$ In order to achieve this end, a worker needed to belong to a labor union. Fox was not interested in political solutions but only those attained through the power of a union. ${ }^{56}$ For example, the right to strike was one of the most important rights of a worker. It was a right that workers attained not by seeking support from politicians and a legislature but by striking in defiance of the law and thereby changing it and public opinion. ${ }^{57}$ As to the necessity of organizing as an industrial union rather than as a craft or trade union, Fox was equally as pragmatic. He reasoned in his column that all workers in an industry, regardless of their specific trade, were essential to the success of the industry. They all belonged to it and through their unity in one union for one industry they would have enormous economic power. ${ }^{58}$ In his columns, he could be highly critical of the IWW for its criticism of his union. He argued that if the Wobblies were true friends of labor, they would support the timber workers, regardless of affiliation, for their union was organized based on industry, just as the IWW argued that all workers should be. Fox defended his union's affiliation with the AFL. The federation's two million members could offer support to the fledgling Timberworker union. According to Fox, the IWW's dual union strategy was not helpful, and Wobbly soap boxing was not leading to the organization of large numbers workers. Moreover, he argued that Wobblies were harmful in their attacks on the Timberworker union. They should be endorsing the effort to build an industrial union in timber and working with, not against, the effort. Fox was critiquing Wobbly orthodoxy, but also the "slamming" of brother unionists, which he contended only benefited employers. ${ }^{59}$ 
In subtle ways, Fox worked his anarchism and syndicalism into the "Dear Jack" columns. In a March entry, he made his thoughts clear as to the nature of the American Revolution and the founding document of the nation. It was a "political revolution," Fox declared, an exchange of one set of bosses for another. He argued that the government was designed to protect the property of the wealthy, who were the ones that created the Constitution, which was concocted in secret. He observed that whenever there was a conflict between capital and labor, the state always moved to support capital and suppresses the rights of workers. He cited current examples of this by citing mining strikes in Michigan and Colorado. ${ }^{60}$ However, he saved his more explicit anarchist perspective for publications such as $W$ hy?, an anarchist journal out of Tacoma, Washington. ${ }^{61}$ Its editor, Sam Hammersmark, was an anarchist friend from Chicago. They were both members of the SLNA and made a similar effort to use syndicalism as a means to achieving an anarchist future. Moreover, he had another venue with his syndicalist writing with The Toiler, a newspaper devoted to "international syndicalism" edited by Max Dezettel. ${ }^{62}$ Nevertheless, it is striking that Fox's radical point of view was welcomed in the pages of the Timberworker. This does help to underscore the radical elements in the AFL, especially among the rank and file and a selective few in positions of leadership. ${ }^{63}$

Fox kept his anarchism and syndicalism embedded in a practical, at the point of production, strategy in the Timberworker. At the union's annual convention, the delegates passed a resolution calling for a strike to gain the eight-hour day for their entire industry. ${ }^{64}$ Fox was there as a vice-president of the union as well as representative from Local 16 of Tacoma, Washington, though he lived at Home Colony and did spend some time living in Seattle. ${ }^{65}$ Fox supported the strike in the newspaper but bowed to the membership, which wished to try to establish the eight-hour day through legislation. Therefore, they wanted to postpone the strike. In his unpublished memories, he wrote, "It came to light that the Socialist Party had secured sufficient signatures to petition for a referendum to be placed on the ballot at the November election calling for a compulsory eight hour day." He, along with the executive board to which he belonged, backed the legislative proposal. During the campaign, employers made it clear that if the referendum passed workers would not get ten hours pay for eight hours of work. Fox reasoned that many workers who barely survived on ten hours pay could not take the loss. The measure failed to become law. Fox further reasoned that this was a sign that if workers wanted the eight-hour day then they would have to "fight for it on the picket line," in other words, at the point of production. ${ }^{66}$

Fox continued to work on the Timberworker over the course of 1914 in his expanded role as a reporter, columnist, and editor. In addition, he served on the executive board for the union and represented his local. Even though the industrial union held a good deal of promise, it was vulnerable. Its first real test of strength came from events overseas that had far-reaching economic consequences. The union faced a serious problem with the outbreak of the First 
World War. Although the war would be "good" for the industry in time, initially it sent the lumber industry in the Pacific Northwest into a depression, throwing mill and timber workers out of work. They roamed the streets of Seattle by the thousands, according to Fox. The union tried to support its members during the crisis, but eventually "the union funds were exhausted." Compounding the union's woes were fifteen strikes and lockouts by January of the following year. Employers were determined to create an open shop in their industry, and, at the end of 1915, the union contended with fifty-five lockouts. The industrial union of timber and mill workers split apart under the strain. Only the shingle workers were able to reconstitute themselves, but as a trade union. Once again the shingle weavers were on their own. ${ }^{67}$

After the demise of the industrial union of timber workers, Fox made his way back to Chicago and resumed his work as a labor journalist. He primarily wrote for the Chicago Labor News from 1916 to 1918, which earned him a living and acclaim in labor circles for his writing. The editor of the News, Max Dezettel, thought at one point that in time Fox could become editor of the AFL's American Federationist. ${ }^{68}$ His topics included the struggle for the eight-hour day, the necessity of the closed shop, women in the labor movement, and the importance of a labor press. Fox even revived his conversational style of writing with a series of articles in which "the dub," a well-meaning but clueless laborer, needs to be educated by "the union man," a character who is patient but pointed in his criticism of "the dub's" ignorance as to the need for a vibrant labor movement and the inherent exploitation of the capitalist system. Also, in Fox's writing during this period, a clear break with the Chicago-based IWW is evident. He argued in several articles in the Chicago Labor News that the IWW was more harmful to the labor movement than helpful. The AFL, he wrote, was far more superior to the labor movement, for it provided workers with a more plausible opportunity to develop industrial unionism. He criticized the IWW as being "autocratic" and lacking in true "radicalism." However, underlying his criticism of the IWW was probably his commitment to syndicalism and the effort to radicalize existing unions rather than creating alternative radical unions in the same industry or trade. Therefore, it makes logical sense that he would want to see the IWW dissolve, for it attempted to pull radicals, such as himself, out of the AFL. Wobblies were actually on the rise during this time period, especially out west in logging, mining, and agriculture. He may have found them to be a threat to the AFL, and his syndicalist efforts. ${ }^{69}$

Fox's "boring from within" tactic was not limited to the AFL. In 1918, he joined the National Nonpartisan League, a movement that had its own "boring from within" strategy that was focused on political parties rather than on the labor movement. The Nonpartisan League tried to influence political parties, especially the Republican Party, in the interests of farmers. The league was non- 
committal in regard to US involvement in the war in Europe. Some league officials were openly antiwar. In North Dakota and elsewhere, the league was especially influential politically and had a friendly relationship with the IWW, for the farmers of the state were heavily dependent on migrant farm labor. ${ }^{70}$ Fox had to take the League's correspondence course in farm economics as preparation for involvement with the organization. ${ }^{71}$ Arthur and Marian Le Sueur ran the League's education department. According to Fox, he considered them to be socialists, with Marian becoming a communist in later years. Marian Le Sueur, in particular, wanted Fox to work in the organization's publicity department because of the League's need for journalists. Fox, however, thought that they were not looking for "the average newspaper man," who tended to "prostitute himself" in service to the mainstream press. Fox moved to the organization's national office in Saint Paul, Minnesota. The "modern office building, from which it directed organization in sixteen states" greatly impressed him. He thought that the League's goal to "capture control of the State Legislatures" was a laudable effort in the interest of agricultural reforms, but he had concerns that without a labor component the League was going to fail. Fox was rather prescient in this point, for the farm labor party movement would rise from the ashes of the NPL. He would later work with the Farm Labor Party in Washington. Nevertheless, Fox was pleased that while working in the publicity department, he and his colleagues "turned out a pile of propaganda." Given his literary aptitude, League officials wanted to transfer Fox to Bismarck, North Dakota, to work on the league's daily newspaper. Fox turned down the offer and noted that "I . . . returned to Puget Sound where the weather was more kind to me." Apparently, the harsh northern Great Plains winters did not appeal to him, and, moreover, he longed to be closer to his many friends in the Pacific Northwest. ${ }^{72}$ In 1918, he returned to Washington and found work in the Ames shipyard in Seattle, secured a position on the staff of the daily labor newspaper, Seattle Union Record, and continued to be active in radical circles, such as with the "radical club" in Seattle where he spoke on anarchism, syndicalism, and other topics. However, it seems clear that his commitment to anarchism was on the wane. The Jay Fox of 1908 would not support the Jay Fox of 1918 in his efforts to influence party politics. Moreover, the ground work was in place for him to be intellectually prepared to accept a new and much more radical political movement in the form of a vanguard party that would dovetail with the concept of the "militant minority." 73

For years, Fox had an extensive personal history with labor unions and strikes. Soon he would take part in his largest and last strike, the Seattle General Strike of 1919. As noted earlier, Fox became a convert to the "general strike" at the beginning of the century. It is clear from his writings that he was influenced by the anarchist Siegfried Nacht's Der Generalstreik and die Sociale Revolution, 
published in 1902 and translated into English in 1905, in which Nacht argued that the path to social revolution was not through the ballot box as German social democrats believed but through a general strike of all workers. Fox was also familiar with Nacht's analysis of French anarchists, who attempted to influence their country's labor unions to embrace this particular strike concept as well. ${ }^{74}$ Fox published his own pamphlet supporting the general strike in 1908. His reflections on the strike that he wrote years later - in an unpublished manuscript - reveal that he was an enthusiastic supporter and believed that the strike had revolutionary syndicalist implications. Fox, though, did not think the strike was the revolution that other participants such as Harvey O'Connor suggested. Moreover, a careful reading of the Minutes of Meetings of the General Strike Committee and Its Executive Committee suggests that the goals of the strike were rather limited in their radicalism. ${ }^{75}$

The strike began initially as a sympathy strike for shipyard workers. It was on 21 January 1919 that shipyard workers put down their tools and withdrew their labor. Employers had promised a wage increase once the war concluded, but that raise did not arrive. Therefore, the workers struck. Early the following month, labor union representatives of the Central Labor Council overwhelmingly voted to have their unions strike in solidarity. Many union organizers were convinced that an open-shop movement was about to begin in the city and this was an opportunity to resist it. The city was completely shut down from 6 February to 11 February, though it reopened under the leadership of the General Strike Committee, composed of 330 representatives from 110 unions. The committee made sure that essential services functioned for the people, especially food distribution. Milk was made available for families and meals made available for workers. The committee also provided a security force that Fox referred to as "Labor's War Veterans Guard." They did not carry weapons but did keep the peace. Furthermore, he asserted that no one was arrested during the entire strike and that the strike was an incredible example of worker solidarity and of the possibility of what a worker controlled society could achieve. ${ }^{76}$ Fox wrote,

As an expression of Labor solidarity the five day Seattle General Strike was a complete success. American Federation of Labor, Industrial Workers of the World, and Japanese workers laid down their tools to the last man and woman; and behold we witnessed for the first time in history a closed city, a city without business and without traffic, accept such as carried the meaningful sign 'Exempt by order of the Strike Committee', the new ruling body now seated in the Labor Temple and elected by the votes of the workers in their union halls. ${ }^{77}$

Although the Seattle General Strike gave Fox hope for a future society run by the working class, he was very frustrated with the decline of anarchism and seems to have come to the point of abandoning it himself. Fox, in similarity to many anarchists and syndicalists, was caught up with the great possibilities of world revolution with the Russians leading the way. He followed the events in 
Russia with keen interest. ${ }^{78}$ By the end of the decade, he was moving in the direction of joining the communist movement. His concern over the decline of anarchism was twofold; one, as a movement, it was not growing. Despite all of the years of a sustained anarchist press, public demonstrations, speeches, affinity groups, and work within labor unions, anarchists were not gaining converts among the working class. He asked rather plaintively, "why didn't they join up with us?" Two, he was able to answer that question when he came to the conclusion that anarchist theory "had become outmoded and ineffective." Nevertheless, he maintained that he "did not desert the cause" as he moved to embrace communism. He wrote, "I could not desert a cause that is a vital part of my intellectual life." From his point of view, he was not "swerving an inch from [his] original purpose." He was still devoted to the emancipation of the working class and the destruction of capitalism, but his path toward that end had changed. He transitioned from an anarchist with a syndicalist strategy to outright communist and member of the party. Nevertheless, in his mind, he was joining a new version of the "militant minority." 79

In the early 1920s, Fox's relationship with William Z. Foster was still quite strong and he seems to have followed his good friend's lead ideologically. As syndicalists they both moved along with others towards both embracing the Russian Revolution and supporting the new and embattled workers' state in Russia along with accepting the direction offered to labor revolutionaries worldwide through the Red International of Labor Unions. ${ }^{80}$ Fox continued to work with Foster's Trade Union Education League (TUEL), which had evolved out of the ITUEL in 1920. Foster brought the organization firmly into the American communist movement after his return from Russia and with the call by the Comintern for all communists to ‘bore from within' established trade and industrial unions. Lenin's Left Wing Communism: An Infantile Disorder was especially influential on syndicalists such as Foster and Fox, who had broken with the IWW's duel union strategy years earlier. It was a vindication of their efforts by the leader of a successful workers' revolution. ${ }^{81}$ 'Boring from within' existing unions merged well with Fox's syndicalism, though anarchism seemed no longer to be the path toward revolution.

Fox's most noteworthy writing during this period was a series of articles for The Labor Herald, the official newspaper of the TUEL. ${ }^{82}$ Amalgamation of trade or craft unions into industrial unions was a primary topic of his journalism. His familiarity with the theory and practice of organizing industrial workers came from direct experience in his association with the IWW and the Timberworkers' union. It extended back even earlier to his work in the Chicago train yards in the 1890s when he worked as a blacksmith in the metal trades. He had participated in the Metal Trades Councils as they attempted to create an industrial union of metal workers in order to prevent trades or crafts from scabbing on each other during work stoppages and act as one union when negotiating with employers. ${ }^{83}$ Fox was committed to working within the AFL to achieve 
industrial unionism, though Samuel Gompers and the union leadership were still holding firm to trade union "ideas and tactics that were 40 years behind 40 years ago." He argued that it was through the "militant workers" in TUEL, working within the AFL that would bring about the necessary changes for labor's emancipation. ${ }^{84}$ Fox set forth a strategy for reorganizing American labor along industrial lines with his TUEL sponsored pamphlet, Amalgamation. Here he briefly laid out the history of the American labor movement, especially the development of its most radical elements, and how it arrived at its present situation in 1923 . He steadfastly maintained an affiliation with the AFL, using the TUEL to transform it. Oddly, his vision of the AFL embracing amalgamation was remarkably similar to the IWW's industrial union structure. However, he articulated a key difference, for the IWW called for a stateless future society to maximize worker liberation. In Amalgamation, Fox explained that "The League subscribes to the formation of a Workers' Republic. It advocates the dictatorship of the proletariat, which means that none but the hand and brain workers, industrial and agricultural, should rule society." 85

The following year Fox joined the Workers (communist) Party. He did not make it public until 1925 in a article entitled "From Anarchism to Communism" in The Workers Monthly, 86 a successor to The Labor Herald that was affiliated with the TUEL and the Workers Party. ${ }^{87}$ In his article, he explained his transformation into a communist but maintained that his ends were still the same. He wrote, "When society will be readjusted on a Communist basis and all will be possessors, when there will be no economic classes in society, then the state will be discarded, its function will be gone." He went on to severely criticize anarchists, such as Emma Goldman, who spoke out against the Russian government, referring to her specifically as "a revolutionary scab." 88 Fox's conversion to communism and his justification for a dictatorship drew attacks from his former anarchist comrades. One of the most hostile critics was the Czech-born anarchist Hippolyte Havel, who was a close associate of Emma Goldman and a founding editor of Mother Earth. He and Fox travelled in the same anarchist circles in Chicago and New York for years. ${ }^{89}$ In the anarchist The Road to Freedom, editor Hippolyte Havel argued that "Fox does not seem to comprehend that the controversy between Bolshevism and Anarchism two opposite theories of life are being fought out - the difference between liberty and authority." Havel went on to charge that Fox always hid his 'anarchism' whenever in the pay of the AFL and did not even think that he really ever was an anarchist. ${ }^{90}$ A more detailed excoriation of Fox followed written by Harry Kelly. Kelly examined Fox's career over the previous ten or more years, finding that the former anarchist had been searching for an ideological home. He wrote, "So after skating around for a number of years trying to find where he belongs, brother Fox lands with both feet in the 'Workers' Party'. Kelly proceeded to challenge each major point that 
Fox made in his article. While Fox tried to explain the necessities behind the controversial policies of the Bolshevik government, Kelly took each one apart, charging that Fox seemed to have no idea how oppressive the Soviet state had become and how counter-revolutionary it was from an anarchist perspective. ${ }^{91}$ Even though both Havel and Kelly made excellent critiques of Fox's support for the Bolsheviks, they did not seem to understand that his motives were tied to his commitment the labor movement. Neither Havel nor Kelly had played any serious role in organizing labor or in the labor movement in general. Nevertheless, they were holding firm to the notion that the ends can never justify the means, a conviction that most anarchists held dear as would the anarchist Fox of years ago.

After the Seattle strike, Fox had moved back to Home Colony. He took an active role in the community and was president of the Mutual Home Association until its dissolution in 1921. He continued to write for periodicals affiliated with the communist movement as well as for the Seattle Union Record. He maintained friendships with Foster and with other communists and left Home on occasion to earn income as a shipyard worker, but also in relation to his work with TUEL and Washington's Farm Labor Party. Even so, he became less active over the course of the 1920s and focused much of his energy in creating a life at Home. The anarchist nature of the community dissipated as the children of the anarchists did not adopt their parents' ideological perspective. Fox maintained close friendships with Home's aging anarchists, former anarchists, and with some of the newcomers to the community. His relationship with Esther had come to an end years earlier and in 1919 he married Cora Peterson, a Danish immigrant and skilled porcelain artist. Together they built a house in Home and began a poultry business, though most of their income was earned through Cora's ability to hand paint porcelain and fine china. They would remain together at Home for the next forty years until Fox's death in 1961. Fox's writing become more introspective later in life and he worked on a memoir that was never finished. His many other writings were on topics that varied from the history of Christianity to Cold War politics, but they all remained unpublished manuscripts. $^{92}$

In many respects, Fox's most active period in the labor movement and as a writer, from the 1890 s to the 1920 s, dovetails well with the history of the left wing of the American labor movement. For most of his career he embraced a libertarian ethic and sought advancements in the cause of labor at the point of production. He, like many radical laborers, struggled to find solutions to the problems workers faced in an industrial capitalist society and did not look to government intervention as a reliable partner for labor that could affect positive changes in the workplace. Workers themselves, guided by a "militant minority," could best manage their work lives through their industrial unions, an economic 
Hall

structure that had revolutionary possibilities. However, the Russian Revolution and the real possibility of a workers' society pulled him, as it did many American radicals, toward a vanguard party as a revolutionary model. For Fox, though, this was just a new incarnation of the "militant minority" that he had been a part of, whether consciously or not, since the 1890s. Of course, the key difference is that the means toward attaining a society administered in the interest of workers would be through a powerful, invasive, undemocratic state rather than through workers' democratically controlled industrial unions. Nevertheless, Fox maintained, in his unfinished memoir, that his life's work had been to motivate workers to sharpen their minds by educating themselves to the true nature of their economic condition, to more actively engage their world, and to in effect emancipate themselves by doing the necessary work of creating a more just and equitable society.

\section{NOTES}

The author thanks Ross Rieder, Edward Johanningsmeier, Peter Cole, and the thoughtful reviewers and editors at Left History for their helpful suggestions on this article. Versions of this essay were presented at the 2009 Social Science History Association Conference in Long Beach, California, and at the Pacific Northwest Labor History Association Conference in 2009 in Seattle, Washington.

${ }^{1}$ Unpublished manuscript by Jay Fox, Box 1, Folder 1, Jay Fox Papers, Special Collections, Foley Center Library, Gonzaga University, Spokane, Washington (hereafter Fox Papers, Gonzaga); Jay Fox, "I was at Haymarket" Our World, 27 April 1951.

2 Unpublished manuscript by Jay Fox, Box 1, Folder 1, Fox Papers, Gonzaga.

${ }^{3}$ Unpublished manuscript by Jay Fox, Box 1, Folder 1, Fox Papers, Gonzaga.

${ }^{4}$ For the Haymarket affair and its aftermath, see Paul Avrich, The Haymarket

Tragedy (Princeton: Princeton University Press, 1984), Bruce C. Nelson, Beyond the Martyrs: A Social History of Chicago's Anarchists, 1870-1900 (New Brunswick: Rutgers University Press, 1988, and James Green, Death in the Haymarket: A Story of Chicago, the First Labor Movement and the Bombing that Divided Gilded Age America (New York: Anchor Books, 2006).

${ }^{5}$ David Montgomery, The Fall of the House of Labor: The Workplace, the State, and American Labor Activism, 1865-1925 (New York: Cambridge University Press, 1987), 2.

${ }^{6}$ For a worker similar to Fox who left behind a body of literature, see Ellen Doree Rosen, A Wobbly Life: IWW Organizer E.F. Doree (Detroit: Wayne State University Press, 2004). 
7 Rosemary Feurer, Radical Unionism in the Midwest, 1900-1950 (Urbana: University of Illinois Press, 2006), David R. Berman, Radicalism in the Mountain West, 18901920: Socialists, Populists, Miners, and Wobblies (Boulder: University of Colorado Press, 2007), Randi Storch, Red Chicago: American Communism at its Grassroots, 1928-35 (Urbana: University of Illinois Press, 2009), Peter Cole, Wobblies on the Waterfront: Interracial Unionism in Progressive-Era Philadelphia (Urbana: University of Illinois Press, 2007).

8 Unpublished manuscript by Jay Fox, Box 1, Folder 1, Fox Papers, Gonzaga; "The American Railway Unions" Jay Fox, Box 1, Folder 7, Fox Papers, Gonzaga; Mary M. Carr, "Jay Fox: Anarchist of Home" Columbia 4 (Spring 1990), 4; Nick Salvatore, Eugene V. Debs: Citizen and Socialist (Urbana: University of Illinois Press, 1982), 127-138.

9 Unpublished manuscript by Jay Fox, Box 1, Folder 2, Jay Fox Papers, Manuscript, Archives, and Special Collections, Holland Library, Washington State University, Pullman (hereafter Fox Papers, WSU).

10 The Demonstrator, 7 December 1904; Candace Falk, ed. Emma Goldman: A Documentary History of the American Years, Volume One Made for America, 1890-1901 (Berkeley: University of California Press, 2003), 565; Free Society had a nationwide circulation and was the only major English-language anarchist newspaper at the time.

11 "Home: A Radical Community" by Jay Fox, Box 1, Folder 25, Fox Papers, Gonzaga.

12 Free Society,14 November 1897; Salvatore, Debs, 164-165; Charles Pierce Le Warne, Utopias on Puget Sound, 1885-1915 (Seattle: University of Washington Press, 1995), 55-58.

13 Free Society, 17 March 1901.

14 Free Society, 28 August, 13 November 1898; for a thorough collection of Errico Malatesta's writings, see Vernon Richards, Errico Malatesta: His Life and Ideas (London: Freedom Press, 1984).

15 Lucien van der Walt and Michael Schmidt, Black Flame: The Revolutionary Class Politics of Anarchism and Syndicalism (Edinburgh: AK Press U.K., 2009), 16.

16 Free Society, 14 April 1901; Several years later Fox would expand on his article in Free Society and publish it as a pamphlet. See Jay Fox, Trade Unionism and Anarchism: A Letter to a Brother Unionist (Chicago: Social Science Press, 1908).

17 Nelson, Beyond the Martyrs, 201-223.

18 Falk, Emma Goldman, 510, 576-577.

19 Carolyn Ashbaugh, Lucy Parsons: American Revolutionary (Chicago: Charles Kerr Publishing Company, 1976), 210-211; "President McKinley Is Shot" by Jay Fox, unpublished manuscript in author's possession.

20 "President McKinley Is Shot" by Jay Fox, unpublished manuscript in author's 
possession.

21 Jay Fox, Roosevelt, Czolgosz and Anarchy (New York: Published by the New York Anarchists, 1901), 2-13.

22 Unpublished manuscript by Jay Fox, Box 1, Folder 21, Fox Papers, Gonzaga; Free Society lacked the necessary subscriptions to stay economically viable.

Therefore, Isaak transferred the current subscribers to The Demonstrator, Free Society, 20 November 1904.

23 Meeting announcements indicate Jay Fox as a featured speaker, Box 1, Folder 17, Fox Papers, WSU.

24 Emma Goldman, Living My Life (New York: Alfred A. Knopf, 1934), 296.

25 The Demonstrator took the place of Free Society as the largest circulating Englishlanguage anarchist communist newspaper in the United States until the publishing of Emma Goldman's Mother Earth. For a thorough history of Home Colony, see Le Warne, Utopias on Puget Sound.

26 The Demonstrator, 2 August 1905; Proceedings, The Founding Convention of the IWW (New York: Merit Publishers, 1969), 612.

27 The Demonstrator, 6 December 1905; Brigitte Koenig, "Law and Disorder at Home: Free Love, Free Speech, and the Search for an Anarchist Utopia" Labor History 45 (May 2004), 211-212; Carr, "Jay Fox," 5.

28 The Demonstrator, 21 August 1907.

${ }^{29}$ Fox, Trade Unionism and Anarchism, 12-13.

30 Carr, "Jay Fox," 5-6.

31 Letter from Charles Govan to Joseph Labadie, 5 February 1910, Joseph Labadie Papers, Special Collections, University of Michigan, Ann Arbor (hereafter Labadie Papers, UM).

32 Candace Falk, Emma Goldman: A Documentary History of the American Years, Volume Two, Making Speech Free, 1902-1909 (Berkeley: University of California Press, 2005), 40-42.

33 "Home: A Radical Community" by Jay Fox, Box 1, Folder 25, Fox Papers, Gonzaga.

34 The Agitator, 1 November 1911.

35 The Agitator, 15 November 1910.

36 The Agitator, 1 March 1911.

37 The Agitator, 1 December 1910.

38 LeWarne, Utopias on Puget Sound, 203-204; Carr, "Jay Fox," 7; Edward Johanningsmeier, Forging American Communism: The Life of William Z. Foster (Princeton: Princeton University Press, 1994), 74.

39 The Agitator, 15 September, 1 November 1911.

40 The Agitator, 15 December 1911. 
41 Fox did not use the term "militant minority," but that is essentially what he was advocating when he argued for anarchists to throw themselves into the labor movement as organizers and agitators; Schmidt and van der Walt, Black Flame, 239-267.

42 Avrich, Haymarket Tragedy, 72-74; Free Society, 14 April 1901; See Fox, Trade Unionism and Anarchism; The Agitator, 15 December 1911; William Z. Foster was an early advocate of and used the phrase "militant minority."

43 Salvatore Salerno, Red November Black November: Culture and Community in the Industrial Workers of the World (Albany: State University of New York Press, 1989), 96-97; The Agitator, 15 February, 1April 1912.

44 The Agitator, 15 April, 1 May, 15 May, 1 June, 15 June, 1 July, 15 July, 1 August, 15 August 1912; Melvyn Dubofsky, We Shall Be All: A History of the Industrial Workers of the World (Urbana: University of Illinois Press, 2000), 128-131; James

R. Barrett, William Z. Foster and the Tragedy of American Radicalism (Urbana: University of Illinois Press, 1999), 47-52; Also see Earl C. Ford and William Z. Foster, Syndicalism (Chicago: Charles H. Kerr, 1990).

45 The Agitator, 15 May, 15 June, 1 July, 15 September, 15 October 1912.

Approximately, during this period, Fox and Esther separated, and Esther became romantically involved with Foster. Nevertheless, the three remained close friends. 46 Letter from Jay Fox to Joseph Labadie, 17 October 1912, Labadie Papers, UM.

47 Carr, "Jay Fox," 8; Charlton J. Brandt, "William Z. Foster and the Syndicalist League of North America” (MA thesis, Sangamon State University, 1985), 30; The Syndicalist, 15 January, 15 March, 1 April 1913.

48 Johanningsmeier, Forging American Communism, 69-71; for a very brief period, anarchists such as Emma Goldman saw great possibilities in syndicalism, though the interest faded rather quickly. For Goldman's views on syndicalism, see Emma Goldman, "Syndicalism: Its Theory and Practice" Mother Earth, November1912, January 1913 and for other New York anarchist views on syndicalism, see Harry Kelly, "A Syndicalist League” Mother Earth, March 1912 and "The Syndicalist Education League," Mother Earth, September 1912.

49 “Organizing Timberworkers” by Jay Fox, Box 1, Folder 13, Fox Papers, Gonzaga.

50 Johanningsmeier, Forging American Communism, 79.

51 “Organizing Timberworkers" by Jay Fox, Box 1, Folder 13, Fox Papers, Gonzaga; for a thorough account of the SLNA, see Brandt, "William Z. Foster and the Syndicalist League of North America," Barrett, Foster, 53-70, and Edward P. Johanningsmeier, "William Z. Foster and the Syndicalist League of North America" Labor History 30 (Summer 1989), 329-353.

52 The Syndicalist, 1 March, 1-15 September 1913; “Organizing Timberworkers" 
Hall

by Jay Fox, Box 1, Folder 13, Fox Papers, Gonzaga; The Timberworker, 1 March 1913, 13 June 1914; Robert L. Tyler, Rebels of the Woods: the I.W.W. in the Pacific Northwest (Eugene: University of Oregon Press, 1967), 64; Shingle weavers were mill workers who made roofing shingles.

53 Letter, “To Whom It May Concern” by J. G. Brown, 17 March 1914, "Organizer and Label Agent Commission" for the American Federation of Labor, 8 April 1914, 8 April 1915, 8 April 1917, Box 1, Folder 7 Fox Papers, WSU.

54 “Organizing Timberworkers" by Jay Fox, Box 1, Folder 13, Fox Papers, Gonzaga; The Timberworker, 6 December 1913.

55 The Timberworker, 20 December 1913.

56 The Timberworker, 3 January 1914.

57 The Timberworker, 17 January 1914.

58 The Timberworker, 31 January 1914.

59 The Timberworker, 6 June 1914; The IWW was actually more successful at organizing lumber workers and loggers than Fox was willing to admit even as of 1914. For a thorough account of the IWW in Pacific Northwest lumber industry, see Tyler, Rebels of the Woods.

60 The Timberworker, 14 March 1914.

61 Why? 1 April 1914.

62 Storch, Red Chicago, 13-17; The Toiler, March 1914, July 1914.

${ }^{63}$ For more information on the diversity within the AFL during this time period, see Julie Greene, Pure and Simple Politics: The American Federation of Labor and Political Activism, 1881-1917 (Cambridge: Cambridge University Press, 1998) and "Symposium on Julie Greene: Pure and Simple Politics" Labor History 40 (May 1999), 189-206.

64 The Timberworker. 24 January 1914; Tyler, Rebels in the Woods, 88-89.

65 The Timberworker, 31 January, 21 March, 23 May 1914.

66 "Organizing Timberworkers" by Jay Fox, Box 1, Folder 13, Fox Papers, Gonzaga; For a thorough account of the Socialist Party in Washington, see Carlos A. Schwantes, Radical Heritage: Labor, Socialism, and Reform in Washington and British Columbia, 1885-1917 (Seattle: University of Washington Press, 1979) and Jeffrey A. Johnson, "They Are All Red Out Here": Socialist Politics in the Pacific Northwest, 1895-1925 (Norman: University of Oklahoma Press, 2008).

67 “Organizing Timberworkers" by Jay Fox, Box 1, Folder 13, Fox Papers, Gonzaga; Tyler, Rebels of the Woods, 88-89; Schwantes, Radical Heritage, 201.

68 Letter from Max Dezettel to Jay Fox, 18 August 1917, Box 1, Folder 2, Jay Fox Papers, Special Collections Division, University of Washington, Libraries, Seattle (hereafter Fox Papers, UW).

69 The Jay Fox Papers at Gonzaga contain an unprocessed box of newspaper 
clippings. Most of the clippings have "Chicago Labor News" handwritten at the end of the piece written by Fox. Some have dates and others do not. However, given the content of the material, it does seem that these articles were written from 1916 to 1918. For the IWW generally for this period, see Melvyn Dubofsky, We Shall Be All and for the IWW and agricultural workers specifically see Greg Hall, Harvest Wobblies: The Industrial Workers of the World and Agricultural Laborers in the American West, 1905-1930 (Corvallis: Oregon State University Press, 2001).

${ }^{70}$ Hall, Harvest Wobblies, 122, 134-135.

71 "The League Correspondence Course in Farm Economics," Box 1, Folder 32, Fox Papers, Gonzaga.

72 “The Nonpartisan League," Box 1, Folder 14, Fox Papers, Gonzaga.

73 Carr, “Jay Fox, 9; Harvey O’Connor, Revolution in Seattle: A Memoir (New York: Monthly Review Press, 1964), 101, 110.

74 See Arnold Roller, The Social General Strike (Chicago: The Debating Club, 1905).

75 Jay Fox, "Seattle General Strike," unpublished manuscript in author's possession; See O'Connor for the "revolutionary" aspects of the strike; Minutes of Meetings of the General Strike Committee and Its Executive Committee at Seattle, Washington, February 2-16, 1919 Box 5, Folder “Seattle General Strike," Harry E.B. Ault Papers, Special Collections, University of Washington Libraries, Seattle. 76 Seattle Union Record, 5 February 1919; Jay Fox, "Seattle General Strike," unpublished manuscript in the author's possession; Minutes of Meetings of the General Strike Committee; For more on the Seattle General Strike, see O'Connor's Revolution in Seattle and Dana Frank, Purchasing Power: Consumer Organizing, Gender, and the Seattle Labor Movement, 1919-1929 (Cambridge: Cambridge University Press, 1994).

77 Jay Fox, "Seattle General Strike," unpublished manuscript in the author's possession.

78 Kenyon Zimmer, "Premature Anti-Communists? American Anarchism, the Russian Revolution, and Left-Wing Libertarian Anti-Communism, 1917-1939" Labor: Studies in Working-Class History of the Americas 6 (Summer 2009), 46-50.

79 Jay Fox, "Why I Joined the Communist Party," Box 1, Folder 2, Fox Papers, Gonzaga; Although Barrett and Johanningsmeier disagree on the extent of the continuity in Foster's transition from syndicalist to communist, it is clear from my research that Fox thought of himself as part of a "militant minority" that was influencing the working class towards their own emancipation.

80 Placing this Bolshevik led effort in its international context, see Reiner Tosstorff (translated by Norry LaPorte) "The Syndicalist Encounter with Bolshevism” Anarchist Studies 17 (2009), 12-28. 
81 Philip Foner, History of the Labor Movement in the United States Volume IX: The T.U.E.L. to the End of the Gompers Era (New York: International Publishers, 1991), 103, 108-126; Bryan D. Palmer, James P. Cannon and the Origins of the American Revolutionary Left, 1890-1928 (Urbana: University of Illinois Press, 2007), 124, 139, 152-154; Barrett, William Z. Foster, 105-117; Unpublished manuscript by Jay Fox, Box 1, Folder 18, Fox Papers, Gonzaga.

82 Foner, History of Labor, Volume IX, 107.

83 In the Chicago City Directory of 1901, Fox's occupation is listed as "Blacksmith"; Jay Fox, "Metal Workers Awake" The Labor Herald (June 1922), 26. 84 Jay Fox, "Reactionary Leadership Must Go," The Labor Herald (January 1923), 21; Jay Fox, "What is a Militant"? The Labor Herald (April 1923), 16-18.

85 See Jay Fox, Amalgamation (Chicago: Trade Union Education League, 1923). 86 Jay Fox, "From Anarchism to Communism," The Workers Monthly (February 1925), 179.

${ }^{87}$ Foner, History of Labor Volume IX, 208.

88 Fox, "Communism," 181; How he could have left a anarchist path to embrace a statist one is difficult to determine. However, perhaps his belief in the withering away of the state as outlined in Lenin's State and Revolution can provide an answer. His personal copy of that particular text from 1924 has clearly underlined passages relating to the post-revolutionary workers' state that was destined to dissolve once the principles of a communist way of life pervaded the entire society. Therefore, at least theoretically a state would simply no longer be necessary.

89 Falk, Emma Goldman, Volume 2, 527.

90 The Road to Freedom (April 1925), 4.

91 Harry Kelly, "From Anarchism to 'Communism' (State Socialism)" The Road to Freedom (April 1925), 5-7.

92 Carr, "Jay Fox," 10; LeWarne, Utopias on Puget Sound, 219-220; “Off to Home Colony" and "Final Adventures," unpublished manuscripts, Fox Papers, Gongaza. 